\title{
From Newton To Gates-Digital Principia
}

E. George Beckwith, National University

Daniel T. Cunniff, National University

\begin{abstract}
Computers are becoming the norm for teaching and learning. The Internet gives people ready access to text, visual and audio messages from around the world. For teachers, content is critical and the future dictates the need for major changes in the role of the teacher and learner. Today's digital tools and video games have proven to be well known motivators. This paper stressed the importance for educators to develop content using these tools and games. We are in the world of interaction and need to be prepared for even more technological advancements. To the extent that instructors keep up with future innovations, will dictate how well these challenges are met and utilized for the betterment of the teaching/learning process.
\end{abstract}

Keywords: Internet, video games, digital tools, teaching/learning process

\section{INTRODUCTION}

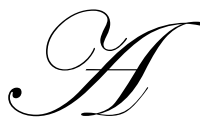

$\mathrm{t}$ an English pub on a recent September evening, the authors were reflecting on their presentations earlier that day at Cambridge University. They had separately given presentations on using new digital media techniques and systems to enhance learning. Dr. Cunniff had focused on distance learning and Dr. Beckwith had focused on gaming. As they talked, they were overlooking King's College—one of the oldest and most architecturally magnificent of all the colleges that comprise Cambridge University. It was not far from Trinity College where Sir Isaac Newton was both a student and a professor. The physical magnificence of Cambridge with all the remarkable academic achievements throughout its $1000+$ year history stood in stark contrast to the mobile world of digital media teaching and learning that the authors had spent that day discussing. The researchers decided that there was a similarity. Just as Newton's new laws of the universe expressed in Principia challenged the academia of his time, so the new digital media principles of today, representative of Gates software programs and Job's mobile platforms, challenges educators in much the same way. Some embrace the new ideas and concepts readily with the changes they bring while others question and resist them.

\section{BACKGROUND OF THE STUDY}

The writers had spent the day both advocating and defending using digital media concepts and systems to move professors and teachers away from the traditional methods that for a thousand years had proven successful at Cambridge toward new mobile, multimedia learning methods, which our and other educator's research indicates, is necessary to engage students and guide their academic success. There is a knowledge gap and a language barrier between traditional professors/teachers and digital age students that grows wider each day. Students embrace learning and communicating via new Internet and mobile-based media while too many teachers/professors resist engaging and using it. The authors thought the essence of this dilemma was captured in a cartoon Dr. Beckwith used in his presentation that day. The cartoon shows three grammar-school age children privately talking in a corner while their grandmother is talking on the phone. The caption is "Grandma's phone is really old fashioned - no movies, no music, no text messaging-you just talk." Considering all the things the small kids listed that their grandma's phone could not do, the realization hit us that though our phones had all those features, we rarely used them and that we were using our phones almost exactly the same way grandma was-just to talk. The researchers, both university professors, then proceeded to consider that though in the masters level courses we taught, we seldom used technology in the way and in the frequency most young people used it. The professors decided to become not only digital media user disciples but users as well. 


\section{STATEMENT OF THE PROBLEM}

The increased use of video conferencing has added to the arsenal of the teaching professor. Computer technology now offers iLinc among other systems, which provides the capability of communicating on three levels of media: audio, visual or text messaging. New vistas are now open to not only students and teachers, but can and does include the business community, partnerships with professors, university classes, and the public at large (Cunniff, 2007). The problem is that there is a gap between the technology and positive, motivational interaction between the teacher and the learner.

\section{PURPOSE OF THE STUDY}

The purpose of the study is to show the need for teaching content that creates a positive, motivational interaction between the teacher and the learner. Research will be cited that will support this hypothesis

\section{Research Question}

Given the current state of the art of video gaming and online education, can the teaching/learning process be enhanced through meaningful, positive, motivational interaction between the teacher and the learner?

\section{DEFINITION OF TERMS}

Wikipedia: Wikipedia (2007) is a multilingual, web-based, free content encyclopedia project. Its name is a combination of the words wiki (a type of collaborative website) and encyclopedia. Wikipedia's articles provide links to guide the user to related pages with additional information. Volunteers from around the world write it collaboratively.

Wikis: Wikis (2007) are websites that can be written upon and edited by multiple users at once. They allow the creation of simple web pages that groups, friends, and families can edit together.

Blogs: (2007) A blog is a personal diary, a daily pulpit, a collaborative space, a political soapbox, a breaking-news outlet, a collection of links. It can be your own private thoughts--memos to the world. Your blog is whatever you want it to be. There are millions of them, in all shapes and sizes, and there are no real rules.

Podcasts: (2007) Unlike traditional broadcasts, which require the listener to tune in at the exact time a program is broadcast, podcasting allows the listener to download a program from the internet when convenient and listen to it on his/her iPod whenever and wherever the listener chooses.

Instant Messaging: Instant messaging (2007) allows instantaneous communication between a number of parties simultaneously, by transmitting information quickly and efficiently, featuring immediate receipt of acknowledgment or reply.

Texting: Texting (2007) is similar to IM but whereas IM is more closely associated with computers and related Bluetooth applications, texting is associated with cell phones and applies to short messages of 160 characters sent to another cell phone subscriber. Some common phrases used are brb (be right back), gtg (got to go), and ttyl (talk to you later).

Video Games: A video game (2007) is a game that involves interaction with a user interface to generate visual feedback on a video device. A review and discussion of some of the current educational video games follows.

IMVU: IMVU (2007) is a graphical instant messaging client with more than 1 million users. Currently, it is in public beta and has been available since April 01, 2004. IMVU, Inc., founded by Will Harvey, a video game developer and founder of There, develops it. The primary focus of IMVU is the ability to use personalized 3D avatars and environments that let the user interact with the person with whom they are chatting. 
YouTube: YouTube (2007) is a video sharing website where users can upload, view and share video clips. Three former PayPal employees created YouTube in mid February 2005. The San Bruno-based service uses Adobe Flash technology to display a wide variety of video content, including movie clips, TV clips and music videos, as well as amateur content such as videoblogging and short original videos.

\section{RELATED LITERATURE}

Marc Prensky (2001) provides an outstanding summation of the skills and knowledge that almost come with being born into the digital age and lists a variety of digital toys and tools that have populated the digital age student since birth. Toys and tools such as computers, video games, video cams, digital music players, cell phones, and hundreds of related applications - all of which intimidate those of us born prior to the digital age. It was in this article that he coined the phrases "Digital Natives" and "Digital Immigrants". He also discusses the different "accents" used by the Natives and the Immigrants and makes the point that the biggest problem in education today is that our immigrant instructors are speaking with an accent or the outdated accent fails to engage the digital natives in their classes. He concludes that because the immigrants set the stage in the classroom and have not taken the time to learn the new digital age language of the natives, they assume that students learn as they always did and continue to try to teach them in the traditional techniques and methods. In his view, we need to confront this native-immigrant issue or just forget about educating Digital natives who in essence will educate themselves.

An article titled "The Madden Curse" (Gonzalez, 2007) depicts an excellent example of another nativewant-to-be by a current adult immigrant. In this case, the writer, a newspaper columnist, describes his temporary quest to become a professional video gamer only to discover that he could not even figure out how to connect his next generation gaming console to the Internet. He concluded that since he was not bright enough to use the gaming hardware, perhaps he did not possess the native ability to play the games effectively.

Timothy VanSlyke (2003) as a 30-something wedged in between the immigrants and the natives, agrees with the differences between the two generations as described by Prensky but disagrees with many of the conclusions that he draws from them. As an in-between who has played video games and employed many of the digital age tools as part of his growing up and employment in the dual university role of assisting faculty in integrating technology into their teaching practices and in teaching some technology courses himself, he has seen the generation gap between the natives and the immigrants first hand. He is not sure that the gap itself is justification for significantly changing the way we teach and learn. According to him, Prensky attributes this gap to the "decline of education in the U.S." and believes that our educational system was not designed to serve today's digital age students.

VanSlyke (2003) makes a counterargument to Prensky based on his belief that the neurological structures of students could not change so dramatically from one generation to the next and that we could be doing our students a disservice by moving away from "legacy" and traditional teaching techniques. He bases this on his experience as a technology instructor wherein he found that though younger students were proficient in using the web, they were less so in doing advanced searches and assessing the validity of what they found. He is also not sure that all students are "Natives" and that demographic differences need to be considered and researched more to determine the impact on students' knowledge and use of digital tools. In quick summary, VanSlyke (2003) appears to agree with Prensky (2001) that students are changing and that different approaches to teaching and learning may be needed, but he is not sure there is sufficient evidence to conclude that traditional professors/teachers need to learn a new language in order to be effective in the subjects and concepts they teach.

Dr. Howard Gardner (2004) would probably agree with VanSlyke for he argues that students today are masters of facts but show little understanding of what the facts mean. Since today's digital tools and video games in particular are well known motivators for those who use the tools and play the games, perhaps it is time for educators to start developing content that teaches understanding using such tools and games. U.S. Senator Joe Lieberman (2001) has made a proposal for just such a partnership. He stated (2001) that people in the gaming industry should reach out to the people in the education community and develop educational games to make learning more exciting 
and representative of the multimedia technology environment in which today's digital-age, school children are growing up.

Computer software has been available for children in the form of video games to use in their homes for many years. Child-friendly computer interfaces brought CD-ROM games into children's environments allowing them to explore stories and games of interest to them. Software speed has increased dramatically over the years so crude, static motion has given way to realistic movements. "Ruff's Bone", for example, is an educational CD-ROM game that can teach children to read as they interact with an animated story. They can use a mouse to explore screen objects with amusing outcomes. An example is having the child click on a birdbath and a diver surfaces, with all the usual sound effects (Calvert, 1999).

Calvert goes on to say, "The internet is a gateway to information throughout the world." The internet connections between personal computers and computer systems throughout the world via phone lines have enabled people to call up a myriad of services from exploring a university library to sending e-mail, to booking reservation, to paying bills, and well as international gaming (Calvert, 1999).

Thomas L. Friedman, author of The World Is Flat states: "Clearly, it is now possible for more people than ever to collaborate and compete in real time with more other people on more different kinds of work from more different corners of the planet and on more equal footing that at any previous time in the history of the world" (Friedman, 2005).

Though some colleges, universities, and K-12 institutions are slowly beginning to support the use of digital tools and games, a campaign is needed to awaken all educators to the potential of such tools and games to enhance our curricula with multimedia, interactive technology that could make the actual as well as the virtual schoolroom a place students will gladly go and enthusiastically learn in a manner that results in understanding and mastery of the subjects they "game." Immigrant educators, particularly those at the higher levels of education in colleges and universities, are not an easy group against which to launch a campaign. They have been told time-and-time again by computer and related technology education advocates that technology would be their savior and rescue them from their unmotivated, discipline-laden, poor-performing students. Research studies to date appear to be inconclusive on just how much, if any, computers and technology have enhanced learning.

One problem with the initial use of technology in the classroom was that it was given to teachers and professors without a stated, refined approach supported by learning theory that was presented with ready-made, technology-rich curricula. Teachers did not have the time or skills (Beckwith, 2001) to change their overhead transparencies and text-oriented lesson plans into multimedia lesson plans and presentations. In essence, they were given technology hardware but were expected to develop their own multimedia curricula—something they were, and still are, in most cases, without the time and expertise to do. Gaming addresses these issues up front starting with learning theory, which strongly supports a gaming approach to education.

In the November 2007 issue of the Chronicle of Higher Education, Carnevale contends that not all students entering college are computer savvy. He believes that students who enroll in community colleges do not always have the extensive backgrounds in technology that college teachers expect. He says some students enter having never used a computer. They are unlike students who enroll in major universities, thus creating a technologyknowledge gap requiring the untrained to take remedial computer classes (Chronicle of Higher Education, 11-2307).

Rosabeth Moss Kanter in her book Evolve! suggests that there is a good deal of attention to the Digital Divide. This is the fact that people in poor neighborhoods and less-developed countries lack access to computers and could fall further behind. She believes that there is a loss of "social capital" (local bonds of service and support) in these poor areas that is critical to child development. Ms. Kanter states, "The issue is not the computer or electronic communications but the social environment itself. The Internet and its close cousins can have a positive effect when the right social context is in place, but a negative effect when it is not. Getting the best of what the online world can offer requires a well-connected offline community" (Kanter, 2001). Positive use of gaming in and out of the school system can have this positive effect. 


\section{LEARNING THEORY AND DIGITAL TOOLS GAMING}

The learning theory, which best fits the use of digital tools and gaming, is the multiple intelligences, an approach to learning developed by Dr. Howard Gardner (2004) of Harvard University. He postulates that there are at least five other intelligences by which we learn and not just the two intelligences of verbal and mathematical on which learning techniques have historically focused. Those intelligences are Bodily-Kinesthetic, Intrapersonal, Interpersonal, Musical, and Spatial, which combined with Verbal and Mathematical, form a synergistic whole of how we learn as an individuals. A definition of most of these intelligences is relatively easy to discern but two of them may need some explanation. Regarding Bodily-Kinesthetic, Dickerson (1999) proposes that learning through gaming and technology is a highly active and interactive process when used appropriately. Students are able to interact with the gaming software and the computers, which rely mostly on eye-hand coordination for their operation - a joy stick as well as the use of the mouse or touch-screen. This kinesthetic activity reinforces learning and makes the student an active participant in the learning process, not just an observer or listener as is normally the case in most traditional classrooms.

\section{POPULARITY OF VIDEO GAMING}

The popularity of video games is due to the physical challenges that the interactive experience and engagement, which the player has with a multimedia virtual universe full of colorful graphics and strange new worlds, to capture and hold the imagination. Games such as "Pong" and "Breakout" were among the first to demonstrate the appeal of this kind of technology. Students, who might otherwise be bored in conventional math classes, even though they call for the same kind of spatial and logical thinking, are quickly and completely captured and engaged by these action-packed challenges.

Dickerson (1999) observed that Visual Spatial intelligence is second nature to today's digital age natives who have grown up watching television and are highly oriented to visual learning. Slides, overhead transparencies, filmstrips, movies, and now gaming are important additions to their learning. Students move from passive observers to active thinkers when interactive systems are also part of the learning process.

The Internet, with today's affordable high-speed connections, has made gaming and multimedia technology (sound, motion, video, podcasts, blogs, wikis, etc.) display of information available at a click of a computer mouse and has opened the door to a tremendous educational potential for on-line classrooms. Unfortunately, as with onground classrooms, the potential for use of multimedia technology as a tool to enhance learning has not been met with widespread application and use. There is hope for there are gaming innovators and creators out there who developing some remarkable games with non-violent, educational applications.

\section{LECTURES ON A PODCAST}

Jeffrey R. Young in his article in The Chronicle of Higher Education "Colleges Try to Make Podcasting of Courses Easier" says that someday professors around the world will podcast their lectures with the touch of a button." He goes on to state that there is a cooperative effort to develop free open-source software led by the University of California at Berkeley. This university started the program called OpenCast and more than 30 colleges have joined an e-mail list to enhance its development. In addition to the technical side, enhancements such as the introduction of gaming and other interactive techniques would support what Cole W. Camplese, director of Educational Technology Services at Pennsylvania State says about focusing on teaching and not just the technical details (Young, 2007).

\section{DIGITAL TOOLS THAT ENGAGE THE MULTIPLE INTELLIGENCES}

Though no single digital tool or application may be as effective as a well-designed video game in engaging the multiple intelligences, when used together in the course of a day, they can have an integrative, synergistic effect in using most of the MI's and assisting students in understanding the information they digest. 


\section{NON-VIOLENT GAMING FOR CHILDREN WITH CANCER}

Re-Mission: David Warhol (Visher, 2006) developed Re-Mission, a 3-D shooting game set in a blood vessel. In this exceptionable educational game, the targets for attack are not the usual terrorists or six headed monsters but cancer cells. This game provides a glimpse of how gaming approaches could be used to address some of the problems and issues in society - in this case, cancer in children. The game was developed to support young cancer patients who can control Roxxi, a nanabot (a miniature robot) as it takes a trip through the body of a fictional cancer patient. The mission of Roxxi is to find and shoot cancer cells while applying methods of treatment. While this battle is going on, an invasion is about to take place by a bout of flu, so Roxxi must also ensure that the immune system stays healthy. Playing this game allows students to understand what is happening to them and learn more about their condition in the process. Warhol believes that the visualization of the game has a profound effect on how quickly and thoroughly children learn about their condition and this in-turn motivates them to take better care of themselves.

\section{NON-VIOLENT GAMING FOR THE CLASSROOM}

Myst: In Tom Ryland's reading and writing class at Chew Magna Elementary School near the British city of Bristol, students sit mesmerized as he displays the dark walls of a hollow mountainside and uses his cordless mouse to guide the cursor down it (Visscher, 2006). He invites and challenges his students to write down which way they would to go to get to a ladder. They must describe what they would come across and experience on their journey down the mountainside. He has found a way, using video games, to make writing fun for his students. Rylands, who possesses great computer and software skills, created Myst, which is a creatively designed series of computer games set on a mysterious deserted island. It can be endlessly navigated to inspire his students' innovation and creativity. The students (ages 9 to 11) in his classes have reached the $93 \%$ mastery of the "level four literacy levels" in reading and writing over the four years in his program compared to an average of $73 \%$ prior to his program at the school and an average of $75 \%$ for all English children (Visscher, 2006).

Myst also includes a blank journal for collecting information, instead of an instruction book. Nine-year olds can differentiate between "rules" for the game and "information" to break codes and solve the game (Kanter, 2001).

\section{IMPACT OF GAMING ON EDUCATION}

Time magazine (2007) provided a very positive view of the impact of gaming on education. It noted that as children, much of our time is spent in imaginary worlds where we substitute toys and make-believe for the real world that we are just beginning to understand and explore. While we play, we also learn; and while we grow, our play becomes more complex as we add rules and goals resulting in something similar to games.

Time (2007) also observes that an entire generation of children has grown up with a different set of games. They play these games in different ways and you watch a kid with a new videogame, you will find that the last thing he/she will do is read the manual. Instead, just start playing to see what happens. The magazine (2007) points out that this is not a random process but rather the essence of the scientific method. Players build a model, through trial and error, of the underlying game based on empirical evidence collected through play. As the players begin to refine this model, they begin to understand and master the game world through a fast cycle of hypothesis, experiment, and analysis. Time points out that it is a fundamentally different take on problem solving than the linear, read-themanual-first approach of their parents.

Finally, Time (2007) postulates, that in this age of structured education and standardized testing, gamers are learning in a totally new way, which means they will treat the world as a place for creation, not consumption. This is the true impact Time believes videogames will have on our culture.

Most games, even the violent ones, teach things that the educational establishment is having great difficulty teaching (Gardner, 2004): problem solving, critical thinking, and understanding, but the setting of most games do 
not take place in the real world in which students live. We need to change the content to reflect the real word as much as possible.

\section{CONCLUSION}

It is time for immigrants/educators at all levels-pre-Kindergarten, Elementary, Middle School, High School, and Colleges to do their homework on the potential of digital age tools and gaming for addressing the problems of educating our natives/children today and in the future. We professors/teachers - the immigrants-- need to learn, as Marc Prensky (2007), proposes, to talk to the students/digital age youth - the natives - in their language. Perhaps as Timothy VanSlyke (2007) believes, it may not be necessary to change completely our traditional approach to teaching but we definitely need to incorporate digital age applications into our methods. It was noted early in this paper that $56 \%$ of professors/teachers do not have their own webpage and $80 \%$ (Souter, 2007) have never done a podcast; having a webpage and doing a podcast may not be key to becoming a native, but the effort could possibly make each of us less of an immigrant and at least help us better understand our students' accents.

\section{REFERENCES}

1. Beckwith, E. (2001). Using Multimedia as an Instructional Tool to Enhance Learning. Disssertation, Bell and Howell Information and Learning Company. Ann Arbor MI.

2. Calvert, S. L. (1999). Children's journeys through the information age. Boston, MA: McGraw-Hill.

3. Carnevale, D. (2007, November 23). Community colleges bridge a tech gap with cell phones and summer camps. The Chronicle of Higher Education.

4. Cunniff, D. T. (2007, June). Education without boundaries. The International Journal of Innovative Higher Education.

5. Dickerson, D. (1999). Teaching and learning through multiple intelligences, Massachusetts: Allyn\& Bacon. ISBN 0-205-29348-4.

6. Diehl, W., (2007, September). The New Social Networking Technologies: Educators Get a Second Life. The $12^{\text {th }}$ Cambridge International Conference on Open and Distance Learning. New Hall, Cambridge.

7. $\quad$ Friedman, T. L. (2005). The world is flat. New York: Farrar, Straus and Giroux.

8. Gardner, (2004). The unschooled mind - how children think and how schools should teach. Basic Books; New York.

9. $\quad$ Gonzalez, J. (2007, November). The Madden Curse. AmericanWay Magazine.

10. Kanter, R. M. (2001). Evolve!. Boston, MA: Harvard Business School Press.

11. Keane, B. (2007). Family Circus. www.familycircus.com. 9-21.

12. Lieberman, J. (2001). Statement of Senator Lieberman regarding Annual Video and Computer Report Card. Available at http://lieberman.senate.gov.

13. Prensky, M. (2001, October). Digital natives, digital immigrants. On the Horizon. NCB University Press. Vol. 9.

14. Souter, K. (2007, September). Social Learning and Second Life. The $12^{\text {th }}$ Cambridge International Conference on Open and Distance Learning. New Hall, Cambridge.

15. Impact of video gaming on education, (2007). Time. Retrieved April 30, 2007, from http://thinklab.typepad.com/think_lab/impact_of video_gaming_on_education/index.html.

16. VanSlyke, T. (2003, May/June). Digital natives, digital immigrants: some thoughts from the generation gap. Commentary in Interact Magazine.

17. Visscher, M. (2006, September). Reading, writing and playing the sims. Ode Magazine, Vol 4, Issue 7.

18. Wikepedia. (2007). Definition of Wikepedia, Wikis, Blogs, Podcasts, IM, .IMVU, YouTube. Retrieved November 5, 2007, from http://en.wikipedia.org/wiki/Wikipedia.

19. Young, J. R. (2007, November 30). Colleges try to make podcasting of courses easier. The Chronicle of Higher Education. 


\section{ABOUT THE AUTHORS}

Dr. E. George Beckwith is currently an Assistant Professor of Educational Technology at National University, San Diego and recently gave presentations at Cambridge University (Gaming Education rather than Violence) and Tulane University (The Gap Between Traditional Professors/Teachers and Digital Age Students). He is responsible for teaching Educational Technology Courses both onsite and has designed, developed and implemented educational technology courses for onsite and online classes. He serves on the NU President's Commission for Online Education, is a member of the Faculty Senate and the Graduate Council. He was previously a Director of Technology at the Inglewood and Los Angeles Unified School Districts and instructed teachers on using multimedia technology in the classroom. He also served as a Computer-Communications Officer in the United States Air Force and retired as a Colonel. His Bachelor's Degree in Experimental Psychology is from the University of Georgia in Athens, his Masters Degree in Educational Psychology is from Wayne State University in Detroit, and his Doctorate in Educational Leadership is from United States International University in San Diego.

Dr. Daniel Cunniff is the Lead Faculty for Educational Administration at National University's Fresno, California, campus. He received his B.S. and M.A. from Northern Illinois University and his Ph.D. from Walden University. He has taught at Portland State University and California State University in San Marcos. He was the recipient of a 2006 President's Professoriate Award for outstanding contributions "above and beyond" his regular work assignments presented by the Chancellor of National University. As an international business analyst, he was an independent consultant to major Fortune 500 companies, including organizations in Indonesia and Canada. He was an Assistant Superintendent for Secondary Education in Fairbanks, Alaska; Educational Advisor of Education Television in American Samoa; Principal and Acting Superintendent in San Diego County; and an Elementary Principal and teacher in the Chicago suburbs. Dr. Cunniff is also the Coordinator of the International Academic Professor Exchange Program for National University, which is based in La Jolla, California. This position has enabled him to present papers on various educational and business topics at international conferences in Las Vegas, Nevada; Mazatlan, Mexico; Panama City, Panama; Belfast, Northern Ireland; Toronto, Canada; and Cambridge University, England. 